\title{
Intellectual Capital Development and its Effect on Technical Innovation in Banks Operating in Jordan
}

\author{
Suha Sameer Al-Khalil \\ Securities Depository Center \\ Capital Market Building, \\ P.O.Box. 212465, Postal Code 11121 Amman, Jordan \\ Tel: 962-779-807-157Ｅ-mail: suha.alkhalil@yahoo.com

\begin{abstract}
Samer Eid Dahiyat
Associate Professor of Strategic Management and Agility

Department of Business Management

Faculty of Business, The University of Jordan

P.O. Box 13276, Postal Code 11942, Amman, Jordan

Tel: 962-775-620-868Ｅ-mail: s.dahiyat@ju.edu.jo
\end{abstract} \\ Mahmoud Ali Al-dalahmeh \\ Assistant Professor of Management Information Systems \\ Department of Management Information Systems \\ Faculty of Business, The University of Jordan \\ Tel: 962-777-552-254Ｅ-mail: m.aldalahmeh@ju.edu.jo
}

Received: Aug. 27, 2013

doi:10.5296/jmr.v6i1.4629
Accepted: December 19, 2013 Published: January 29, 2014

URL: http://dx.doi.org/10.5296/jmr.v6i1.4629

\begin{abstract}
The purpose of this study is to investigate the effect of intellectual capital development on the ability of banks operating in Jordan to undertake technical innovation. Employing a questionnaire-based survey, twenty banks out of twenty six participated, and 163 out of 200
\end{abstract}




\section{Macrothink}

questionnaires were returned and were valid for analysis, thus resulting in a response rate of 81.5\%. Exploratory Factor Analysis (EFA) results show that intellectual capital consists of two main dimensions: Human Capital, and Structural Capital comprising items originally developed to reflect organisational capital and relational capital. Also, product/service and process innovation items converged to form one construct named Technical Innovation. Multiple regression analysis findings show a significant and positive effect of the aforementioned intellectual capital dimensions on technical innovation. More specifically, structural capital was proved to have a stronger effect on technical innovation compared with human capital. These findings highlight the need for organisations intent on enhancing their technical innovative capabilities to not merely focus on attracting and recruiting highly skilled and competent human resources, but rather, they are advised to develop mechanisms designed to capture and translate the knowledge and expertise of organisational members and stakeholders so that these become internalized in the organisation's processes and routines.

Keywords: Intellectual capital, Technical innovation, Human Capital, Structural Capital 


\section{Introduction}

The twenty-first century business environment is often characterized by dynamism, fierce competition, globalization, rapid technological changes, and short product life cycles (Grant, 1996). In light of this environmental reality, business organisations are continuously challenged to offer improved and innovative products and services in order to outperform competitors and deliver enhanced value (Teece, 2007). As such, a fundamental requirement for achieving competitive superiority is to maintain uniqueness through innovation. In this context, tangible resources, such as financial resources and physical resources that encompass raw materials, land, equipment, tools and machines, have been rendered as merely insufficient for building and maintaining competitive advantage. Instead, the organisation's focus should shift to intangible resources, particularly knowledge-based ones represented by the skills, experiences, capabilities, and competencies of an organisation's human resources, as a new basis for surviving and thriving in today's "knowledge-based economy" (Andriessen, 2004). Such an importance of intangible (knowledge-based) resources, including employees' knowledge, experiences and skills, as well as an organisation's reputation, brand names, procedures, and relationships with stakeholders, has been especially echoed by the recent shift in the strategic management thinking, represented by the resource and knowledge-based views which consider capabilities and competencies as the main sources for creating and maintaining competitive advantage (Barney, 1991, 1995, 1996, 2001; Teece \& Pisano, 1994; Iansiti \& Clark, 1994; Grant, 1996; Teece, Pisano, and Shuen, 1997; Hitt, Keats, and De Marie, 1998; Petroni, 1998; Eisenhardt \& Martin, 2000; Teece, 2007). As such, knowledge resources and innovation have become inextricably interlinked, as organisations that are proficient at creating and applying knowledge have a better chance of preventing rigidity and encouraging innovative behaviour, thus generating sustained competitive advantage (Chen et al., 2010; Xu et al., 2010).

In this context, intellectual capital has emerged as a concept of increased importance for managers and researchers who are interested in knowing how firms can derive their profits from innovation via exploiting their knowledge resources (Edvinsson \& Sullivan, 1996; Stewart, 1997; Diaz-Diaz, Aguiar-Diaz, and De Saa-Perez, 2008). The manner in which the construct of intellectual capital facilitates the exploitation of knowledge-based resources is illustrated by the three main components widely argued to make up this construct, namely: human capital, which represents the knowledge and skills of employees; organisational capital, which represents the translation of the human knowledge and capabilities into procedures, processes, technologies, patents, culture, structure and strategy; and relational capital, which enhances the knowledge and capabilities stock through informal interactions among organisational employees and relationships with external stakeholders (Bontis, 1998; Canibano, Garcia-Ayuso, and Sanchez, 2000; Subramaniam \& Youndt, 2005). The effective exploitation of an organisation's intellectual capital is believed to facilitate innovation in organisations, which can take a number of forms: it can either be in the form of a new product or service, a new production / process technology, or a new structure or administrative system (Damanpour, 1991). Thus, innovation is categorized into two main types, technical innovation (product innovation and process innovation) and administrative 
innovation.

A review of relevant literature has revealed that most studies related to intellectual capital and technical innovation have taken place in a limited number of countries, particularly in Spain, Canada, and China (Bontis 1998, 2001, 2004; Wang \& Chang, 2005; Diaz-Diaz et al., 2008; Hormiga, Canino, and Sanchez-Medina, 2010; Santos-Rodrigues, Dorrego, and Jardon, 2011). Accordingly, conducting a study of this type in an emerging country context such as that of Jordan is believed to help in shedding some light on this timely topic concerned with investigating the possible effects of intellectual capital on technical innovation, especially when taking into consideration the scarcity of physical resources in Jordan and the huge emphasis being placed upon, and investments that have and are being made in, human resources, within the context of policies aiming at transforming Jordan's economy into a knowledge-based one. This is in accordance and response to the calls voiced by Bontis (2004), who urged Arab countries to focus on intellectual capital and make it their top priority. The main driver behind this call lies in the over-dependence of Arab countries' economies on oil; a non-renewable resource, and the absence of clear strategies to invest in knowledge and intellectual capital as key anchors for the economy of the future. Moreover, applying this study on the banking sector, which is regarded as a "Knowledge Intensive Business Sector" KIBS where investment in and exploitation of knowledge-based resources and intellectual capital is often considered the driver of organisational competitiveness, further adds to the value of this study.

Based on this, the main aim of this research is to investigate the effect of intellectual capital development on the technical innovation capability of banks operating in Jordan. More specifically, our research objectives are:

1. To explore the main dimensions of intellectual capital as perceived by banks operating in Jordan.

2. To identify the levels of intellectual capital development as well as technical innovation (product/service and process) in banks operating in Jordan.

3. To investigate the effect of intellectual capital dimensions on technical innovation in banks operating in Jordan.

\section{Research model}

\subsection{Innovation}

As competition is becoming increasingly global and intense, and markets are changing rapidly driven by continuously-developing technologies and sophisticated customers' expectations and needs, maintaining an organisation's competitiveness in such a hostile environmental reality is proving to be more difficult without investing in innovation-related capabilities. Innovation is now viewed as the means by which organisations can better respond to the changes taking place in today's twenty-first century business environment. The reasons being are that an innovative organisation is more capable of: (1) learning about and pursuing customers' needs; (2) developing new products or services that address those needs; 
and (3) developing and implementing internal processes and activities that enhance understanding and fulfilment of customers' needs (Damanpour, 1991; Narver, Slater, and MacLachlan, 2004). Evidently, innovation is not only considered as a source of competitive advantage but also competitive necessity, as organisations' mere survival is increasingly dependent on it. Some of the positive impacts of investing in innovation include improved organizational performance, enhanced adaptability, and long-term survival (Damanpour, 1991; Hult, Hurley, and Knight, 2004).

There have been a number of attempts in the extant literature to describe and define innovation. These range from referring to innovation as a source of sustained competitive advantage; an organisation-wide phenomenon; a process; and a new operating philosophy for twenty-first century organisations. More specifically, innovation has been described as representing the capacity to introduce a new product or service, a new production process, or a new structure or administrative system in the organisation (Damanpour, 1991; Hurley \& Hult, 1998). In a similar vein, innovation is often regarded as encompassing three clearly-distinct stages or types: innovation as a process, innovation reflected in a discrete item including products, programs, or services, and innovation as an attribute of organizations (Baregheh, Rowley, and Sambrook, 2009). In all of its phases, innovation typically starts with idea generation and ends with commercialization. The various definitions of innovation in the extant literature highlight the point that it is the continuous creation and delivery of value to organisational stakeholders, most important of which are its customers, that is considered the impetus behind the emphasis placed upon innovation. For example, West and Anderson (1996) define innovation as the effective development and application of processes and products new to the organization, which are designed to enhance the value delivered to its stakeholders. Also, Weerawardena (2003) refers to innovation as the application of ideas that are new to the organization to create added value for the organisation and its stakeholders, particularly customers, whether the newness and added value are embodied in products, processes, services, or in work organisation, management or marketing systems.

Numerous classifications and typologies of innovation are found in the literature. However, the most widely accepted typologies of innovation is that proposed by Damanpour (1991), who indicates that the concept of innovation is composed of both: technical innovation, and administrative innovation. Technical innovation is related to products, services, marketing, as well as new production process technologies developed to create products or deliver services. Administrative innovation, on the other hand, is related to organisational structure and administrative activities. Regardless of the form of innovation, whether it is technical (product/service and process) or administrative, a review of the literature reveals that all types of innovation fall under a continuum referred to as the degree of innovation, with two extremes: incremental and radical. Incremental innovation is defined as the ability to reinforce, recombine, and take advantage of existing knowledge resources (Danneels, 2002; Subramaniam \& Youndt, 2005). Outputs of incremental innovation are slight variations of existing products, services, practices or approaches (Damanpour, 1991). Conversely, radical innovation is based on knowledge resources that an organization does not yet have or that differ from existing resources (Danneels, 2002). In this study, the focus is on technical 
innovation, as Han, Kim, and Shrivastava, (1998) argue that the traditional meaning of the term "innovation" mostly refers to technical innovation.

\subsubsection{Technical innovation}

Innovation, particularly product and process innovation, has become a key aspect of business success (Alegre, Lapiedra, and Chiva, 2005). Technical innovation is primarily concerned with the development and adoption of new knowledge that is integrated into products, services, or processes (Damanpour, 1991; Cooper, 1998). Thus, this type of innovation is directly related to the organisation's basic work activities, production processes, and technologies used in producing products or providing services. As such, technical innovation is classified into: 1) Product/ service innovation, and 2) Process innovation (Utterback \& Abernathy, 1975; Damanpour, 1991; Damanpour and Gopalakrishnan 2001). Product/service innovation is primarily concerned with developing new products/services in order to meet customers' needs by focusing on creating new benefit or value, either by enhancing a current product/service or developing a new innovative product/service (Utterback \& Abernathy, 1975; Damanpour, 1991). Product/ service innovation is crucially important for organisations that are intent on defending existing market share and/or gaining new ones. Intensive interaction between an organisation and its customers encourages customers to provide suggestions that may be useful in introducing new products or services (Droge, Jayaram, \& Vickery, 2004). Examples of product/service innovations introduced by banks along the years include Automatic Teller Machines (ATMs), debit cards, credit cards, personal banking and mortgage equity accounts, amongst many others (Damanpour \& Gopalakrishnan 2001). Process innovation, on the hand, is concerned with developing an organisation's manufacturing or service delivery process operations, through introducing new production techniques, methods, procedures, machineries, equipment, processes, task specifications, and workflow mechanisms (Damanpour, 1991; Damanpour \& Gopalakrishnan, 2001). Unlike product innovation, process innovation focuses on improving the productivity and efficiency of the organisation's operational activities. Examples of process innovation introduced by banks include automated voice response systems, customer information files, and risk management systems (Gopalakrishnan, Bierly, \& Kessler, 1999).

\subsection{Intellectual capital}

Despite numerous studies examining intellectual capital, no single definition has been universally adopted. Nevertheless, most definitions of the concept share common aspects or dimensions. For example, Stewart (1997) defined intellectual capital as a package of useful knowledge that includes an organisation's processes, technologies, patents, employees' skills, and information about customers, suppliers and stakeholders. Roos, Roos, Dragonetti, and Edvinsson (1997) highlight in their definition the importance of practically translating organisational members' knowledge into a competitive asset, in terms of trademarks, patents, and brands, if such knowledge is to be considered as part of an organisation's intellectual capital. Edvinsson \& Malone (1997) also echo the importance of developing organisational knowledge in such a way so as to make it practical and business-oriented if it is to be considered part of its intellectual capital repertoire. Forms of such knowledge include applied 
experience, organisational technology, customer relationships, and professional skills, which can provide an organisation with a competitive edge in the marketplace. Sveiby (1998) highlighted in his definition of intellectual capital two basic aspects; one that is human-specific, reflected in the knowledge, experiences, and brainpower of employees, and another one that is organisation-specific, reflected in the knowledge resources stored in an organisation's databases, processes, culture and philosophy. As such, it is concluded that the collection of an organisation's knowledge-based (intangible) resources and their flows, and the conversion of the resulting knowledge into competitive advantage, value, and profit, are what form the core of an organisation's intellectual capital (Harrison \& Sullivan, 2000; Bontis, 2001; Wang \& Chang, 2005). Table 1 summarises the main definitions of intellectual capital.

As to the conceptual dimensions of intellectual capital, the classification that has achieved a certain degree of consensus includes three main dimensions (Edvinson \& Malone, 1997; Sveiby, 1997; Bontis, Keow, and Richardson, 2000; Sanchez, Chaminade, and Olea, 2000; MERITUM, 2002; Youndt, Subramaniam, \& Snell, 2004; Subramaniam \& Youndt, 2005). These are:

1) Human capital, which represents the collective knowledge of employees comprising their experiences, skills, and know-how.

2) Organisational capital, which reflects organisational knowledge in the forms of technologies, patents, manuals, processes, and culture.

3) Relational capital, which refers to knowledge that has emerged through informal interactions among employees and relationships with external stakeholders.

Based on these dimensions, it is concluded that the development of intellectual capital is the result of building up and utilising distinctive knowledge resources on the part of an organisation, through internal and external stakeholders, organisational routines, technologies, and intellectual property. 
Table 1. Main Definitions of Intellectual Capital

\begin{tabular}{|l|l|}
\hline \multicolumn{1}{|c|}{ Authors } & \multicolumn{1}{|c|}{ Definitions of (IC) } \\
\hline Roos et al. (1997) & $\begin{array}{l}\text { The sum of knowledge of company's members and practical } \\
\text { translation of their knowledge, such as trademarks, patents, and } \\
\text { brands. }\end{array}$ \\
\hline Edvinsson \& Malone (1997) & $\begin{array}{l}\text { The possession of knowledge, applied experience, organisational } \\
\text { technology, customer relationships, and professional skills that } \\
\text { provide a company with a competitive edge in the market. }\end{array}$ \\
\hline Stewart (1997) & $\begin{array}{l}\text { A package of useful knowledge that includes an organisation's } \\
\text { processes, technologies, patents, employees' skills, and information } \\
\text { about customers, suppliers, and stakeholders. }\end{array}$ \\
\hline Sveiby (1998) & $\begin{array}{l}\text { It is the knowledge, experiences, brainpower of employees, as well as } \\
\text { knowledge resources stored in an organisation's databases, systems, } \\
\text { processes, culture, and philosophy. }\end{array}$ \\
\hline Harrison \& Sullivan (2000) & Knowledge that can be converted into profit. \\
\hline Bontis (2001) & The collection of intangible resources and their flows. \\
\hline Wang \& Chang (2005) & $\begin{array}{l}\text { Assert that intellectual capital assists enterprises in promoting } \\
\text { competitive advantage and value. }\end{array}$ \\
\hline $\begin{array}{l}\text { Huang, Luther, and Tayles } \\
\text { (2007) }\end{array}$ & $\begin{array}{l}\text { A composite of the wisdom, intelligence, flexibility, creativity, } \\
\text { entrepreneurship, and core competencies necessary to succeed in an } \\
\text { increasingly competitive global economy where technology and } \\
\text { knowledge dominate. }\end{array}$ \\
\hline
\end{tabular}

\subsection{Hypothesis Development}

The growing interest in intellectual capital can be attributed to organisations that build their business success upon the ability to innovate (Edvinsson \& Sullivan, 1996; Alegre et al., 2005). Such organisations often operate in what is known as "Knowledge Intensive Business Sectors" (KIBS); a term that clearly ties an organisation's innovation capabilities to its ability to develop and utilize its knowledge resources, through the development of intellectual capital (Subramaniam \& Youndt, 2005). This contention has been supported by a number of studies that have linked intellectual capital and innovation, in that intellectual capital is considered as an input to the innovation process, and that innovation is regarded as the result of intellectual capital development and utilisation (Cohen \& Levinthal, 1990; Nonaka, 1994; Tsai \& Ghoshal, 1998; Ahuja, 2000; Subramaniam \& Youndt, 2005). In particular, prior research findings (Garcia \& Calantone, 2002, Subramaniam \& Youndt, 2005; Chen, Lin, and Chang, 2006; Wu, Wann-Yih, Chang, Man-Ling, \& Chen, Chih-Wei, 2008; Al-Dujali, 2012) show that intellectual capital dimensions are closely interrelated and play an essential role in supporting technical innovation (Elsetouhi \& Elbeltagi, 2011). Hence, when a company enhances its intellectual capital, it is expected to have more innovative competence to further enhance its new product and/or process development performance. For example, many researchers have pointed out that human capital is a crucial input in the innovation process and the development of new products, services, and processes (Bontis, 1998; Bontis, 1999; 
Wang \& Chang, 2005; Santos-Rodrigues et al., 2010, 2011; Elsetouhi \& Elbeltagi, 2011). Human-embodied knowledge, which takes the forms of skills, experiences, competencies, talents, creativity, amongst others, make up an organisation's human capital (Stewart, 1997; Roos, 1998; Van Buren, 1999; Katila \& Ahuja, 2002; Subramaniam \& Youndt, 2005; Seleim $\&$ Khalil, 2011), and is considered the source, from which ideas and solutions that can enhance existing products, services, and processes, and/or develop new ones, emerge. In service organisations- including banks- human capital plays an obviously vital role in delivering enhanced value, due to close interactions between employees and customers/clients in the service delivery process, leading to greater emphasis being placed upon peoples' knowledge, capabilities and competencies. As such, human capital reflected in employees' actions and decisions bears significant influence on customers' perceived value (Namasivayam \& Denizci, 2006). However, it is worth noting that human capital cannot be owned by organisations (Stewart, 1997). Any knowledge and expertise of individuals will not stay within the organisation as employees may retire, leave the organisation, or may be simply unwilling to share their crucial tacit knowledge in order to protect and enhance theirpower and status in the organisation. Hence, the second dimension of intellectual capital, which is organisational capital, comes into play as it transforms embodied knowledge into non-embodied one that is incorporated and internalised in the organisation.

Organisational capital, also referred to as structural capital, differs from human capital in that it refers to the knowledge embedded and internalised in the organisation, and as such has become part of the organisation's knowledge repertoire and intelligence. It is the result of not only the sum of employees' knowledge but also the sharing of tacit, embodied knowledge among organisational members and its conversion into explicit, non-embodied one, which reduces the risk of its loss, particularly in the cases of employee turnover or exit. To facilitate the capturing of human-embodied knowledge and its conversion from tacit to explicit, the organisation acquires, codifies, and stores such knowledge in a number of forms including databases, knowledge management systems, patents, manuals, organisational structures and cultures, processes, and information systems ((Edvinsson \& Malone 1997; Roos \& Roos, 1997; Bontis 1998; Subramaniam \& Youndt, 2005). From an organisational learning perspective, such conversion of knowledge and its subsequent storage in formal systems is believed to enable the organisation to improve its future performance (Huber, 1991; Sinkula, 1994). Organisational capital supports technical innovation activities in a number of ways: First, information is stored in databases and made available to all those who might need it, which enables organisational members to benefit from it. Second, prior studies (Wu et al., 2008; Elsetouhi \& Elbeltagi, 2011; Al-Dujali, 2012) have found that the knowledge resources stored in databases, manuals, processes, and culture strongly contribute to the creation of new ideas concerning the organisation's products and processes. Therefore, well-developed organisational capital provides a good environment for rapid knowledge sharing, collective knowledge growth, shortened lead times, and a higher level of employee productivity (Stewart, 2000). This is believed to significantly support employees' activities and enhance their ability to generate and innovate new ideas, thus fostering overall organisational innovation. 
Due to today's dynamic and uncertain business environment, it has become an established fact that organisations do not and cannot operate as closed, isolated entities, but rather, they are often regarded as open systems that continuously interact with their external environment. Emanating from this, an organisation's knowledge resources need to be continuously renewed and made relevant to the changing demands, needs, and expectations of its environmental stakeholders. Therefore, relational capital was developed to define the relationships between an organisation and its stakeholders, including its customers, suppliers, other external partners, as well as its internal stakeholders, particularly employees (Roos et al., 1997; Bontis, 1999; Subramaniam \& Youndt, 2005). Through these relationships, knowledge is shared between an organisation and its stakeholders, which provides opportunities for learning that effectively contribute to the ability of the organisation to create new knowledge and introduce innovations. Accordingly, one of the most important aspects of relational capital is the relationships that develop between the organisation and its customers, since those represent the cornerstone of innovation-related activities (Mayo 2001). Another aspect of relational capital refers to the relationships that develop among employees within the organisation (Nahapiet \& Ghoshal, 1998; Subramaniam \& Youndt, 2005), through which employees exchange their knowledge, experiences, and know-how via social networks that develop over time through informal interactions. As such, this component of intellectual capital includes both internal relationships (between the employees of a single organisation) and external relationships (between an organisation and its customers, suppliers, and others) (Hormiga et al., 2010). Intra- as well as inter-organisational cooperation and social interactions play a vital role in determining the extent of knowledge exchange and exposure, which in turn has an important positive effect on product and process innovation (Tsai \& Goshal, 1998; Chang, 2003; Zerenler, Hasiloglu, \& Mete, 2008; Mention, 2012). For example, employee contacts, personal relationships, communication, and joint participation in experimentations and discussions are believed to facilitate the rapid obtaining and integration of knowledge (Nahapiet \& Ghoshal, 1998). The resulting new knowledge can well enhance the level of product/process innovation performance. On the same hand, interactions with external partners can have fruitful bearings upon product/service innovation, since feedback and inputs obtained from these external stakeholders can modify and/or change the final features of products or processes significantly (Teece, 2007). In other words, if an organisation is proficient at combining and utilising the diverse ideas and knowledge acquired from its external partners, especially customers, it can enhance its innovation activities through introducing creative changes to its products and processes.

The aforementioned discussion leads to our research hypothesis:

H1: There is a positive and significant effect of intellectual capital (human, organisational, and relational) on technical innovation (product/service and process).

Figure 1 shows the theoretical framework developed in this research, which reflects its hypothesis. 


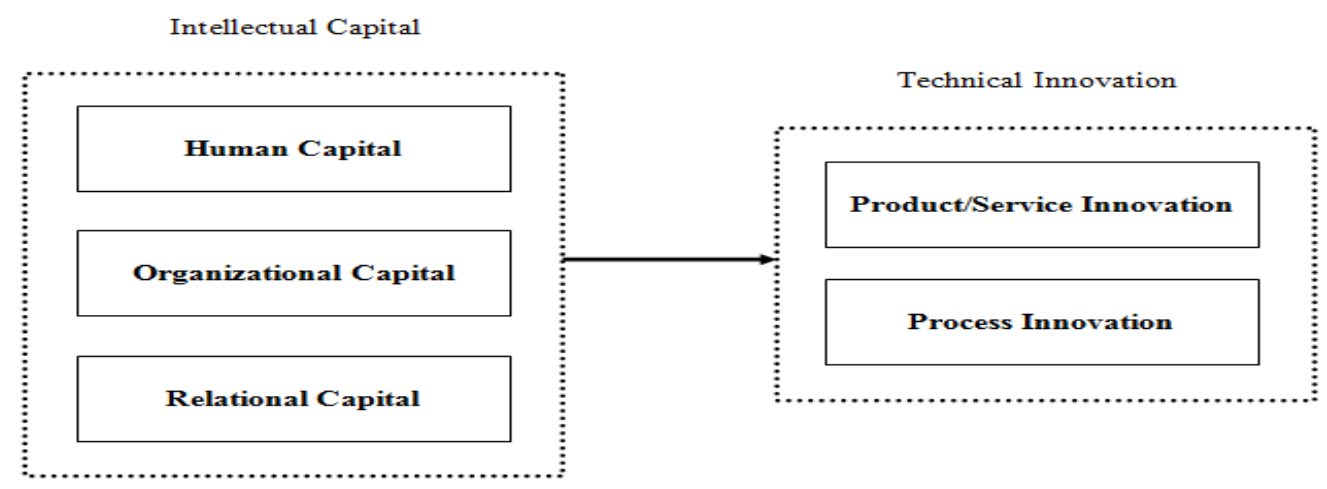

Figure 1. Research Theoretical Framework

\section{Research Constructs Operationalisation}

After developing the research model and hypothesis, there is a need to measure the main variables depicted in the research theoretical framework in order to gather primary data for the purpose of testing the research hypothesis. After reviewing relevant studies, a number of items were developed to measure the research constructs and their respective dimensions (See table 2). Accordingly, intellectual capital dimensions were measured through developing items by referring to Bontis (1998), Youndt et al. (2004), and Seleim \& Khalil (2011), as follows: six items for "human capital", five items for "organisational capital", and six items for "relational capital". Technical innovation dimensions were measured through developing items by referring to Wang and Ahmed (2004) and Nasution, Mavondo, Matanda, and Ndubisi, (2011), as follows: six items for product/service innovation, and five items for process innovation.

\section{Research Methodology}

The research followed a survey design where a structured questionnaire was used. The research population consisted of all twenty six banks operating in Jordan, whether those were foreign or domestic. All of the twenty six banks were contacted in person through their human resources and public relations departments and invited to participate in the research survey. Twenty out of twenty six banks agreed to participate, which represented $80.7 \%$ of the whole population. The unit of analysis consisted of knowledge workers who held managerial positions in the headquarters of the participating banks, including those in the top management level (i.e. senior managers), the middle management level (i.e. divisional managers), the lower management level (i.e. heads of departments and supervisors), as well as employees. Those were targeted since their managerial duties and responsibilities are related to the activities normally associated with building/developing the dimensions of the intellectual capital of an organisation (i.e. human, relational, and organisational). Also, they are involved in the bank's planning and delivery of banking products/services. Consequently, multiple respondents at different managerial levels within each bank were targeted by the survey since intellectual capital dimensions are developed collectively through 
"organisation-wide" efforts rather than being the sole or individual responsibility of a specific work unit or person. The same rationale applies in the case of product/service and process innovation. As such, including multiple respondents in the survey would ensure higher representativeness and reduce bias.

The vast majority of questionnaires were delivered by hand, and the remaining questionnaires were sent electronically via E-mail. A total of two hundred (200) questionnaires were distributed, and one hundred and seventy one (171) out of two hundred (200) questionnaires were returned. Eight (8) of those were eliminated due to missing data or unsuitability for analysis, thus resulting in one hundred and sixty three (163) questionnaires being valid for analysis. Based on this, the response rate was $81.5 \%$, which is considered a very high one (Dillman, 1978; Hair, Anderson, Tatham, \& Black, 1998). Table 3 presents the characteristics of participating respondents and banks. As shown in Table 3, nearly one third of the respondents have a good experience in their industry amounting to 10-15 years. Nearly half of the banks (45.4\%) are large employing more than 1,000 personnel with (66.9\%) employing more than 751personnel. This indicates that these banks are well-established in their industry and are supposed to provide valued data that reflect their wide experience. Most of the respondents $(62.6 \%)$ hold a bachelor degree. The vast majority of the banks $(82.2 \%)$ are local. In addition, nearly one third of the respondents (33.1\%) are supervisors and a quarter of them $(25.2 \%)$ are heads of departments.

\section{Analysis and Results}

\subsection{Validity and Reliability}

The content and face validity of the research instrument was assured through following a number of procedures, which are: (a) conducting a thorough examination of the relevant literature addressing intellectual capital and technical innovation, (b) designing the measurement items by referring to well-known studies, in which researchers have developed and used reliable scales to measure the same constructs, (c) conducting a pilot study phase before starting the survey, whereby five academics specialised in the areas of knowledge management, strategic management, and operations management acted as referees for the questionnaire. In addition, ten practitioners working in two banks were interviewed and asked for their comments and suggestions regarding the phrasing and design of the questionnaire items. The collective feedback gained was used to refine the design of the questionnaire and its items. 
Table 2. Measurement of the research constructs

\begin{tabular}{|c|c|c|}
\hline \multicolumn{2}{|r|}{ Intellectual Capital: IC } & References \\
\hline \multicolumn{2}{|r|}{ Human Capital: HC1-HC6 } & \multirow{20}{*}{$\begin{array}{c}\text { Bontis } \\
(1998) ; \\
\text { Youndt et } \\
\text { al (2004); } \\
\text { Seleim \& } \\
\text { Khalil } \\
\text { (2011) }\end{array}$} \\
\hline $\mathrm{HC} 1$ & The bank's employees are highly skilled & \\
\hline $\mathrm{HC} 2$ & The bank's employees are creative in that they are capable to generate new ideas. & \\
\hline $\mathrm{HC} 3$ & The bank's employees are considered experts in their particular jobs and functions. & \\
\hline $\mathrm{HC} 4$ & The bank's employees focus on providing quality services. & \\
\hline $\mathrm{HC} 5$ & The bank's employees are able to find simple solutions for complex problems. & \\
\hline HC6 & The bank's employees lack the ability to provide new ideas. & \\
\hline \multicolumn{2}{|r|}{ Organisational Capital: OC1-OC5 } & \\
\hline OC1 & The bank documents knowledge in manuals and databases. & \\
\hline $\mathrm{OC} 2$ & $\begin{array}{l}\text { The bank's business processes are reflected in work mechanisms, structures and } \\
\text { systems. }\end{array}$ & \\
\hline OC3 & The bank's culture promotes effective ways of doing business. & \\
\hline OC4 & $\begin{array}{l}\text { The bank possesses work methods and procedures that support innovation and } \\
\text { development of new products and services. }\end{array}$ & \\
\hline OC5 & $\begin{array}{l}\text { The bank protects knowledge and key information to avoid loss if key people } \\
\text { decided to leave the bank. }\end{array}$ & \\
\hline \multicolumn{2}{|r|}{ Relational Capital: RC1-RC6 } & \\
\hline $\mathrm{RC} 1$ & The bank's employees collaborate with each other to solve problems. & \\
\hline $\mathrm{RC} 2$ & The bank's employees share information and learn from one another. & \\
\hline $\mathrm{RC} 3$ & $\begin{array}{l}\text { The bank's employees communicate and exchange ideas with each other from } \\
\text { different divisions and departments of the bank. }\end{array}$ & \\
\hline $\mathrm{RC} 4$ & $\begin{array}{l}\text { The bank's employees partner with customers, suppliers, and other stakeholders to } \\
\text { develop business solutions. }\end{array}$ & \\
\hline $\mathrm{RC} 5$ & The bank values the clients' feedback and opinions. & \\
\hline RC6 & The bank's employees are reluctant to share their knowledge and experience. & \\
\hline & Technical Innovation: $T I$ & References \\
\hline \multicolumn{2}{|r|}{ Product/ Service Innovation: PRIN1- PRIN6 } & \multirow{12}{*}{$\begin{array}{c}\text { Wang \& } \\
\text { Ahmed } \\
\text { (2004); } \\
\text { Nasution et } \\
\text { al. (2011) }\end{array}$} \\
\hline PRIN1 & The bank introduces modifications to its existing products or services. & \\
\hline PRIN2 & The bank constantly develops new products or services. & \\
\hline PRIN3 & The bank's new products and services are often perceived as novel by customers. & \\
\hline PRIN4 & In new product and service introductions, the bank is often first-to-market. & \\
\hline PRIN5 & $\begin{array}{l}\text { In comparison with the bank competitors, your bank has introduced more } \\
\text { innovative products and services during the past five years. }\end{array}$ & \\
\hline PRIN6 & $\begin{array}{l}\text { In comparison with the bank competitors, your bank has a lower success rate in } \\
\text { products and services. }\end{array}$ & \\
\hline \multicolumn{2}{|r|}{ Process Innovation: PCIN1- PCIN5 } & \\
\hline PCIN1 & The bank's work processes are constantly updated. & \\
\hline PCIN2 & The bank emphasizes the development of new ways of providing its services. & \\
\hline PCIN3 & The bank allocates a particular budget to develop new processes and technologies. & \\
\hline PCIN4 & The bank constantly uses up-to-date technology to enhance product and service & \\
\hline
\end{tabular}


PCIN5 In comparison with the bank competitors, your bank is late in adopting new technology related to bank's activities.

Table 3. Research respondents' characteristics

\begin{tabular}{lcc}
\hline Respondent's characteristics & Frequency & Percentages \\
\hline Job Title & 22 & 13.5 \\
\hline Senior Manager & 35 & 21.5 \\
Divisional Manager & 41 & 25.2 \\
Head of Department & 54 & 33.1 \\
Supervisor & 11 & 6.7 \\
Other & & \\
\hline Educational Level & 0 & 0.0 \\
\hline Secondary Education & 15 & 9.2 \\
Diploma & 102 & 62.6 \\
Bachelor & 45 & 27.6 \\
Master & 1 & 0.6 \\
Doctorate & & 11.0 \\
\hline Experience Years & 18 & 23.9 \\
\hline Less than 5 years & 39 & 31.3 \\
5-less than 10 years & 51 & 20.2 \\
10-less than 15 years & 33 & 13.5 \\
15-less than 20 years & 22 & \\
20 years and more & & 10.4 \\
\hline Bank Size (number of employees) & 12 & 10.4 \\
\hline Less than 250 & 17 & 21.5 \\
250-less than 500 & 25 & 45.4 \\
500-less than750 & 35 & \\
750-less than1000 & 74 & 100.0 \\
1000 and more & 163 & \\
\hline Bank Nationality & & \\
\hline Local & & \\
Foreign & & \\
\hline Total & & \\
\hline & & \\
\hline
\end{tabular}

With regard to construct validity, Exploratory Factor Analysis (EFA) was performed to test the components of the intellectual capital and technical innovation constructs, in terms of identifying the dimensions that exist measurement items. To conduct the EFA, four assumptions were followed (Hair et al., 1998; Field, 2000): (1) sampling adequacy (Kaiser-Meyer-Olkin measure greater than 0.5); (2) the minimum eigen value for each factor to be one; (3) a factor loading of 0.40 for each item as the threshold for item retention, and (4) 
varimax rotation was used. To conduct the EFA, the variables of study should be normally distributed; this makes it possible to generalize the results of the analysis beyond the sample collected (Field, 2000). Therefore, a Kolmogorov-Smirnov (K-S) test was performed. The result of the test indicated that the data are not normally distributed. To accommodate this non-normality, the research constructs were transformed by taking the square root transformation and logarithm transformation. Data transformation is an acceptable way to reduce the variability of data, as long as the same mathematical application is performed on every observation. According to Stevens (2009), data transformation is allowed because it simply involves applying a mathematical process to the data to reduce the variability. Tables 4 and 5 show the results of EFA for the intellectual capital and technical innovation constructs, respectively. Kaiser's measure of sampling adequacy was (0.947) for intellectual capital items, and (0.937) for technical innovation items, and Bartlett's test of Sphericity Chi-square $\chi 2$ was statistically significant $(p \leq 0.00)$ in both cases; thus suggesting that factor analysis is appropriate for analyzing the data in both instances. Also, eigen values for the resulting factors in the case of both constructs were greater than one, and all items had loadings greater than 0.4 and communalities greater than 0.5 . Fulfilling the aforementioned assumptions, a two-factor model of intellectual capital emerged explaining $65.003 \%$ of the total variance. All of the seventeen items originally developed to measure the intellectual capital construct loaded on two factors. The first factor, with $57.391 \%$ of the total variance, was labelled 'Structural Capital' and includes all items originally developed to measure organisational and relational capitals (OC1-OC5, and RC1-RC6). The second factor, with $7.612 \%$ of the total variance, was labelled 'Human Capital' and includes all six items originally developed to measure it (HC1-HC6), without any additions or deletions. With regard to technical innovation items, a one-factor model labelled "Technical Innovation" emerged explaining $68.095 \%$ of the total variance, and consisted of all eleven items originally developed to measure the construct (PRIN1-PRIN6, and PCIN1-PCIN5).

The reliability of constructs was measured by calculating Cronbach's alpha coefficient for the factors that resulted from EFA. The closer the value of Cronbach's alpha is to one, the higher the degree of internal consistency among items (Hair et al., 1998; Field, 2000). Table 6 shows all constructs were highly reliable, ranging from 0.890 to 0.933 . Table 7 shows the means and standard deviations for each of the three constructs, as well as Pearson's correlations among them. Note that the a five-point Likert scale was used to measure the extent to which Human Capital (HC), Structural Capital (SC), and Technical Innovation (TI) are practiced and evident in banks operating in Jordan, where 1 represents "never", 2 "rarely", "3" some of the time", 4 "most of the time", and 5 "always". It can be seen that respondents' answers were between "some of the time" and "most of the time", which indicates an "above medium" level of practice.

\subsection{Descriptive analysis and correlation}

Table 7 shows the means and standard deviations for each of the three constructs, as well as Pearson's correlations among them. Note that the a five-point Likert scale was used to measure the extent to which Human Capital (HC), Structural Capital (SC), and Technical Innovation (TI) are practiced and evident in banks operating in Jordan, where 1 represents 
"never", 2 "rarely", "3" some of the time", 4 "most of the time", and 5 "always". It can be seen that respondents' answers were between "some of the time" and "most of the time", which indicates an "above medium" level of practice.

In multiple regression analysis, multicollinearity (strong correlation between more than two predictor/independent variables in a regression model) is an important issue that needs consideration (Field, 2000). There are many ways of identifying multicollinearity. One measure is the correlation matrix of all the independent variables. To ensure that there is no multicollinearity, the independent variables must not have correlations of above 0.80 or 0.90 (Field, 2000). The above table indicates that the Pearson's correlation between the two independent variables ( $\mathrm{HC}$ and $\mathrm{SC}$ ) is 0.757 , which is below 0.80 and thus does not present any serious concerns.

Table 4. Exploratory Factor Analysis (EFA) results for the intellectual capital construct

\begin{tabular}{|l|l|c|}
\hline \multicolumn{2}{|c|}{ Intellectual Capital: dimensions and items } \\
\hline OC1 & The bank documents knowledge in manuals and databases. & Factor loadings \\
OC2 & $\begin{array}{l}\text { The bank's business processes are reflected in work mechanisms, structures } \\
\text { and systems. }\end{array}$ & 0.550 \\
OC3 & The bank's culture promotes effective ways of doing business. & 0.656 \\
OC4 & The bank possesses work methods and procedures that support innovation and & 0.658 \\
& development of new products and services. & 0.642 \\
OC5 & The bank protects knowledge and key information to avoid loss if key people & 0.582 \\
& decided to leave the bank. & \\
RC1 & The bank's employees collaborate with each other to solve problems. & 0.714 \\
RC2 & The bank's employees share information and learn from one another. \\
RC3 & The bank's employees communicate and exchange ideas with each other from & 0.827 \\
& different divisions and departments of the bank. & 0.809 \\
RC4 & The bank's employees partner with customers, suppliers, and other & 0.765 \\
& stakeholders to develop business solutions. & \\
RC5 & The bank values the clients' feedback and opinions. & 0.649 \\
RC6 & The bank's employees are reluctant to share their knowledge and experience. & 0.724 \\
\hline \multicolumn{2}{|c|}{ Human Capital HC } & Factor loadings \\
\hline HC1 & The bank's employees are highly skilled & 0.816 \\
HC2 & The bank's employees are creative in that they are capable to generate new & 0.814 \\
HC3 & ideas. & The bank's employees are considered experts in their particular jobs and \\
functions. & The bank's employees focus on providing quality services. & 0.759 \\
HC5 & The bank's employees are able to find simple solutions for complex problems. & 0.711 \\
HC6 & The bank's employees lack the ability to provide new ideas. & 0.764 \\
\hline
\end{tabular}


Table 5. Exploratory Factor Analysis results for the technical innovation construct

\begin{tabular}{|c|c|c|}
\hline \multicolumn{3}{|c|}{ Technical Innovation: dimensions and items } \\
\hline \multicolumn{2}{|r|}{ Technical Innovation } & Factor loadings \\
\hline PRIN1 & The bank introduces modifications to its existing products or services. & 0.855 \\
\hline PRIN2 & The bank constantly develops new products or services. & 0.874 \\
\hline PRIN3 & $\begin{array}{l}\text { The bank's new products and services are often perceived as novel by } \\
\text { customers. }\end{array}$ & 0.797 \\
\hline PRIN4 & In new product and service introductions, the bank is often first-to-market. & 0.768 \\
\hline PRIN5 & $\begin{array}{l}\text { In comparison with the bank competitors, your bank has introduced more } \\
\text { innovative products and services during the past five years. }\end{array}$ & 0.777 \\
\hline PRIN6 & $\begin{array}{l}\text { In comparison with the bank competitors, your bank has a lower success rate } \\
\text { in products and services. }\end{array}$ & 0.786 \\
\hline PCIN1 & The bank's work processes are constantly updated. & 0.844 \\
\hline PCIN2 & $\begin{array}{l}\text { The bank emphasizes the development of new ways of providing its } \\
\text { services. }\end{array}$ & 0.888 \\
\hline PCIN3 & $\begin{array}{l}\text { The bank allocates a particular budget to develop new processes and } \\
\text { technologies. }\end{array}$ & 0.835 \\
\hline PCIN4 & $\begin{array}{l}\text { The bank constantly uses up-to-date technology to enhance product and } \\
\text { service quality. }\end{array}$ & 0.859 \\
\hline PCIN5 & $\begin{array}{l}\text { In comparison with the bank competitors, your bank is late in adopting new } \\
\text { technology related to bank's activities. }\end{array}$ & 0.785 \\
\hline
\end{tabular}

Table 6. Reliability of research constructs

\begin{tabular}{|l|c|c|}
\hline Construct & Number of items & Cronbach's alpha \\
\hline Human Capital & 6 & 0.890 \\
Structural Capital & 11 & 0.923 \\
Technical Innovation & 11 & .933 \\
\hline
\end{tabular}

Table 7. Means, standard deviations and Pearson's correlations

\begin{tabular}{|l|c|c|c|c|c|}
\hline Construct & Mean & S.D. & $\mathbf{1}$ & $\mathbf{2}$ & $\mathbf{3}$ \\
\hline Human Capital & 3.652 & .746 & 1.000 & & \\
Structural Capital & 3.755 & .742 & .757 & 1.000 & \\
Technical Innovation & 3.790 & .823 & .687 & .791 & 1.000 \\
\hline
\end{tabular}

Correlation is significant at the 0.01 level (2-tailed).

\subsection{Hypothesis testing}

The research hypothesis was tested by regressing Human capital and Structural capital on Technical Innovation, using multiple regression analysis. Table 8 shows the results of the multiple regression analysis. To predict the goodness-of fit of the model, the multiple correlation coefficient (R), coefficient of determination (R2), and F ratio were examined. 


\section{Macrothink}

First, the R of independent variables (HC and SC) on the dependent variable (TI) is 0.802 , which shows that TI has a positive and high overall association with the two IC dimensions. Second, the R2 is 0.644 , suggesting that $64.4 \%$ of the variation in TI was explained by the two IC dimensions. Last, the $F$ ratio, which explains whether the results of the regression model could have occurred by chance, had a value of $144.605(\mathrm{p}=0.00)$ and was considered significant. This means that at least one of the IC dimensions was important in contributing to TI. In the regression analysis, the beta coefficients are used to explain the importance of the two independent variables in contributing to the variance in the dependent variable. The importance is as follows: structural capital $(B=0.635, p=0.000)$ had the strongest effect on technical innovation, followed by human capital $(B=0.206, p=0.005)$. In conclusion, the results of multiple regression analysis indicate that there is a positive and significant effect of intellectual capital dimensions (human capital and structural capital) on technical innovation.

Table 8. Multiple Regression Model: Dependent variable: Technical Innovation

\begin{tabular}{|l|c|c|c|c|c|}
\hline \multirow{2}{*}{} & \multicolumn{2}{|c|}{ Unstandardized Coefficients } & $\begin{array}{c}\text { Standardized } \\
\text { Coefficients }\end{array}$ & \multirow{2}{*}{ Sig. } \\
\cline { 2 - 5 } & B & Std. Error & Beta & \\
\hline Constant & .025 & 0.19 & & 1.323 & .188 \\
Human Capital & .220 & .077 & .206 & 2.847 & .005 \\
Structural Capital & .649 & .074 & .635 & 8.800 & .000 \\
\hline R & \multicolumn{5}{|c|}{0.802} \\
R2 & \multicolumn{7}{|c|}{0.664} \\
Adjusted $R$ 2 & \multicolumn{7}{|c|}{0.639} \\
Regression $\boldsymbol{F}$-value & \multicolumn{7}{|c|}{144.605} \\
\hline
\end{tabular}

$\mathrm{p}<0.05$

Stepwise regression analysis was also used to identify the strongest predictors of TI (see Table 9). As a result, two models emerged, which were both significant: Model 1 ( $F=269.23$, $\mathrm{p}<0.05)$, Model $2(\mathrm{~F}=144.61, \mathrm{p}<0.05)$. Model 1 consists of structural capital as the main predictor, with an R2 of (0.63), thus explaining alone $63 \%$ of the variance in TI. Model 2 consists of both predictors (human capital and structural capital), with an R2 of (0.64), thus slightly increasing the explanatory power when adding human capital as a second predictor. Table 9 shows that structural capital has a noticeably stronger effect on technical innovation $(\beta=0.64)$, compared with human capital $(\beta=0.21)$. 
Table 9. Stepwise Multiple Regression Analysis: Dependent variable: Technical Innovation (TI)

\begin{tabular}{|c|c|c|c|c|c|c|c|c|c|}
\hline Model & $\begin{array}{c}\text { Unstdized } \\
\text { Coeffs B }\end{array}$ & $\begin{array}{c}\text { Std. } \\
\text { Error }\end{array}$ & $\begin{array}{c}\text { Stdized } \\
\text { Coeffs } \\
\text { Beta }\end{array}$ & $t$ & Sig. & $F$ & $\boldsymbol{R}$ & $R 2$ & $\begin{array}{l}A d j \\
R 2\end{array}$ \\
\hline 1 Structural Capital & .81 & .05 & .79 & 16.41 & .000 & $269.23 *$ & .79 & .63 & .62 \\
\hline 2 Structural Capital & .65 & .07 & .64 & 8.80 & .000 & 144 6 & 00 & 6 & 14 \\
\hline Human Capital & .22 & .08 & .21 & 2.85 & .005 & & & & \\
\hline
\end{tabular}

\section{Discussion and Conclusion}

This study has contributed to the areas of Knowledge Management (KM), in general, and Intellectual Capital (IC), in particular, as it has shed some light on the importance of developing and exploiting an organisation's intellectual assets and capital in the vein of supporting its Technical Innovation (TI) capabilities. It does so by empirically validating the theoretical components that make up IC, as well as investigating their effects on TI, from an emerging economy context. As such, it is considered one of a limited number of studies to be conducted in this field in Jordan, which helps in broadening the conceptualisation of such concepts deemed vital in today's "knowledge economy" and encapsulated through Grant's (1996) knowledge-based view of the firm. This study can thus be regarded as a timely response to the calls voiced by Bontis (2004), who urged Arab countries to focus on building and developing their intellectual capitals in an effort designed to establish a solid foundation for the future competitiveness of their industries and national economies. The banking industry was chosen as the population for this study since it is considered a knowledge-intensive one, where survival and continuity are based on adopting knowledge harvesting and exploitation as the means for building an innovation-based advantage. Thus, this research has sought to fill a gap in middle-east related business studies by providing a considerable basis for expecting how intellectual capital may affect technical innovation.

More specifically, this study investigated the effects of intellectual capital development, represented by its two main dimensions of human capital and structural capital, on the ability of banks operating in Jordan to undertake technical innovation, in terms of product/service and process innovation. The results of the study indicated a positive and significant effect of the aforementioned dimensions of intellectual capital on technical innovation capability. This finding is consistent with previous studies, which highlighted the vital and instrumental role of intellectual capital and knowledge management in significantly enhancing and supporting an organisation's innovation capabilities, particularly in the vein of developing new products/services and processes (Tsai \& Goshal, 1998; Bontis et al., 2000; Chang, 2003; Wang \& Chang 2005; Chen et al., 2006; Wang et al., 2008; Wu et al., 2008; Zerenler et al., 2008; Santos-Rodrigues et al., 2010, 2011; Elsetouhi \& Elbeltagi, 2011, Al-Dujali, 2012; Mention, 2012). In particular, structural capital was found in this study to have a noticeably stronger effect on technical innovation, compared with human capital. This finding highlights 
the need for organisations intent on enhancing their technical innovative capabilities to not merely focus on attracting and recruiting highly skilled and competent human resources, but rather, such organisations are advised to develop mechanisms designed to capture and translate the knowledge, expertise, and skills of organisational members and stakeholders so that these become internalised in the organisation's processes and routines, in the vein of facilitating technical innovation. This important finding is consistent with and adds further support to the concept of absorptive capacity, which is essentially regarded as an organisational knowledge management effort designed to assimilate valuable knowledge and incorporate it within the organisation's existing repertoire of capabilities and competencies, thus significantly enhancing organisational efforts to develop new innovative solutions and core competencies (Cohen \& Levinthal, 1990; Zahra \& George, 2002; López-Sáez, Navas-López, \& Martín-de-Castro, 2010; Park, 2011; Dahiyat \& Al-Zu'bi, 2012).

These two main activities of absorptive capacity resemble the contribution made by structural capital, which is reflected in the dual effects of: translating individual knowledge resources and incorporating them into the organisation's knowledge repository (organisational capital), and creating new knowledge through facilitating knowledge sharing relationships among employees and with external stakeholders (relational capital). This is also in tune with EFA results, in terms of the emergence of structural capital as an IC dimension comprised of all the items originally developed to reflect both: organisational as well as relational capital. As such, organisational capital and relational capital can be thought of as two enablers that collectively support structural capital in capturing and institutionlising human-embodied knowledge (human capital), thus developing "Intellectual Capital". This notion is echoed by Edvinsson \& Malone (1997), when they indicate that human capital and structural capital encompass intellectual capital when integrated together (see figure 2). While human capital refers to individual knowledge, skills, experiences and capabilities, whether those pertain to organisational members and/or stakeholders (customers, suppliers, partners, etc.) (Roos, 1998; Stewart, 1997; Youndt et al., 2004; Subramaniam \& Youndt, 2005), structural capital represents the incorporation of such individual-based knowledge resources into those of the organisation, and the regeneration of such knowledge through relational capital (Bontis, 2001). 


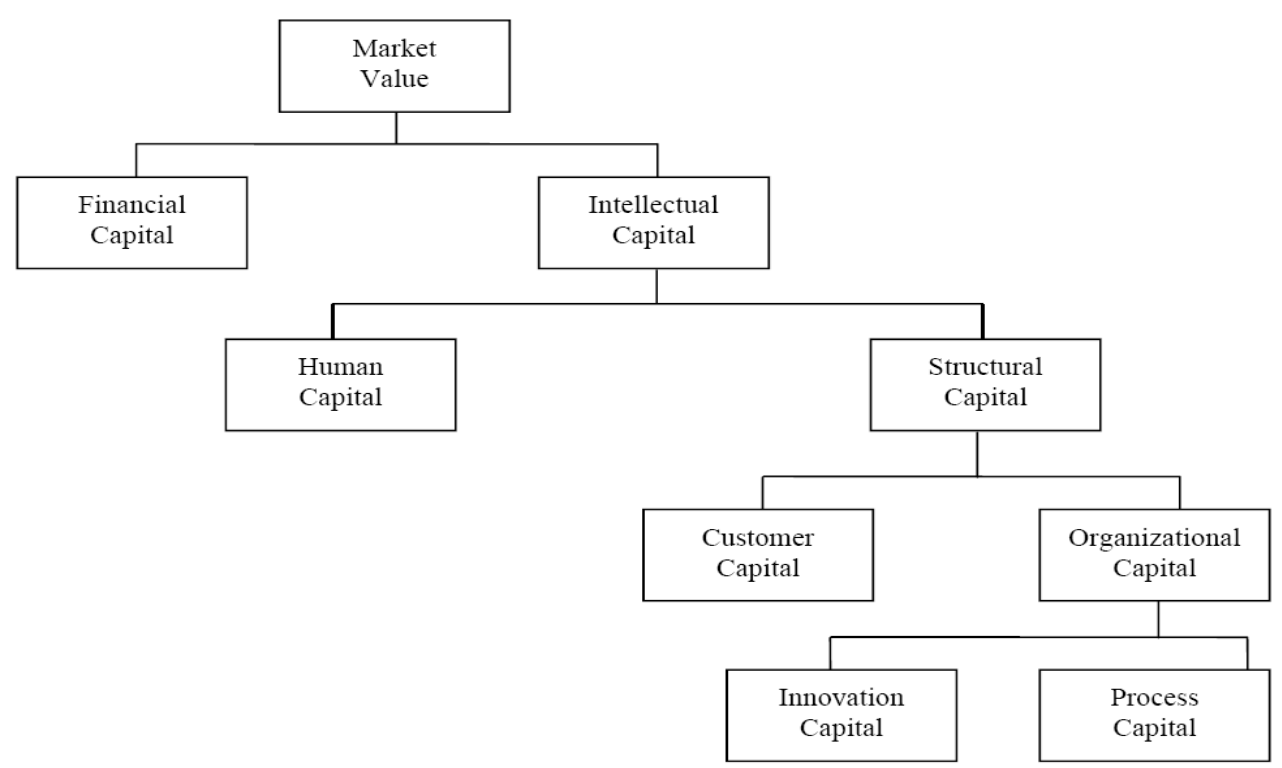

Figure 2. IC Framework by Edvinsson and Malone (1997). Source: Jashapara, A. (2011). Knowledge Management: An Integrated Approach. UK: Prentice Hall: 74.

The results also reveal that banks operating in Jordan showed a fairly high level of intellectual capital development, exhibited by its two dimensions of human and structural capitals. Results also show a similar level of technical innovation capability. These findings indicate an acknowledgement on the part of banks operating in Jordan of the important role assumed by intellectual capital in enhancing the value delivered to customers, through supporting organisational innovation efforts, which ultimately leads to the building and sustaining of competitive advantage. This positive attitude toward embracing intellectual capital and technical innovation reflects the fierce and aggressive nature of the banking industry in Jordan and elsewhere, where the development and exploitation of technical innovations in the form of product/service and process innovations based on the commercial harvesting of knowledge, is widely recognized as a key requirement for maintaining competitiveness (Abor, 2005; Trott, 2005). In particular, and in light of the study's findings, banks are advised to invest in building and developing their human capital, in terms of devising a Human Resource Management Strategy that delineates and nurtures critical skills and competencies needed to enhance overall value delivered to stakeholders. More importantly, organisational routines and mechanisms have to be put in place so as to facilitate both: the capturing of human-embodied knowledge as well as the incorporation of it into the organisation's intellectual assets. Additionally, banks are advised to foster social interactions and cross-functional coordination and linkages among its knowledge workers. Moreover, it is recommended that they pay more attention to managing their external relationships with key stakeholder groups.

\section{References}

Abor, J. (2005). Technological innovations and banking in Ghana: an evaluation of 
customers' perceptions.

IFE

Psychologia,

$13(1)$

170-187.

http://dx.doi.org/10.4314/ifep.v13i1.23668

Ahuja, G. (2000). Collaboration networks, structural holes, and innovation: A longitudinal study. Administrative Science Quarterly, 45(3), 425-455. http://www.jstor.org/stable/2667105

Al-Dujali, M. (2012). Influence of Intellectual Capital in the Organisational Innovation. International Journal of Innovation, Management and Technology, 3(2), 128-135.

Alegre, J., Lapiedra, R., \& Chiva, R. (2005). A literature-based innovation output analysis: implications for innovation capacity. International Journal of Innovation Management, 9(4), 385-399. http://dx.doi.org/10.1142/S1363919605001319

Andriessen, D. (2004). Making sense of intellectual capital: Designing a method for the valuation of intangibles. Amsterdam, Boston: Elsevier.

Baregheh, A., Rowley, J., \& Sambrook, S. (2009). Towards a multidisciplinary definition of innovation. Management Decision, 47(8), 1323-1339. http://dx.doi.org/10.1108/00251740910984578

Barney, J. (1991). Firm Resources and Sustained Competitive Advantage. Journal of Management, 17(1), 99-120. http://dx.doi.org/10.1177/014920639101700108

Barney, J. (1995). Looking Inside For Competitive Advantage. The Academy of Management Executive, 9(4), 49-61. http://www.jstor.org/stable/4165288

Barney, J. (1996). The Resource-Based Theory of The Firm. Organisation Science, 7(5), 469. http://dx.doi.org/10.1287/orsc.7.5.469

Barney, J. (2001). Is the Resource-Based View a Useful Perspective for Strategic Management Research? Yes, Academy of Management Review, 26(1), 41-56. http://www.jstor.org/stable/259393

Bontis, N. (1998). Intellectual Capital: An Exploratory Study that Develops Measures and Models. Management Decision, 36(2), 63-76. http://dx.doi.org/10.1108/00251749810204142

Bontis, N. (1999). Managing organisational knowledge by diagnosing intellectual capital: framing and advancing the state of the field. International Journal of Technology Management, 18(5), 433-462. http://dx.doi.org/10.1504/IJTM.1999.002780

Bontis, N., Dragonetti, N. C., Jacobsen, K., \& Ross, G. (1999). The knowledge Toolbox: A Review of Tools Available to Measure and Manage Intangible Resources. European Management Journal, 17(4), 391-402. http://dx.doi.org/10.1016/S0263-2373(99)00019-5

Bontis, N., \& Girardi, J. (2000). Teaching knowledge management and intellectual capital lessons: an empirical examination of Tango simulation. Journal of Technology Management, 20(5), 545-555.

Bontis, N., Keow, W., \& Richardson, S. (2000). Intellectual capital and business performance in Malaysian industries. Journal of Intellectual Capital, 1(1), 85-100. http://dx.doi.org/10.1108/14691930010324188 
Bontis, N. (2001). Assessing knowledge assets: a review of the models used to measure intellectual capital. International Journal of Management Reviews, 3(1), 41-60. http://dx.doi.org/10.1111/1468-2370.00053

Bontis, N. (2004). National intellectual capital index: A United Nations initiative for the Arab region. Journal of Intellectual Capital, 5(1), 13-39. http://dx.doi.org/10.1108/14691930410512905

Chang, Y. (2003). Benefits of co-operation on innovative performance: Evidence from integrated circuits and biotechnology firms in the UK and Taiwan. $R$ and $D$ Management, 33(4), 425-437. http://dx.doi.org/10.1111/1467-9310.00308

Chen, Chung-Jen, Huang, Jing-Wen, \& Hsiao, Yung-Chang (2010). Knowledge management and innovativeness: The role of organizational climate and structure. International Journal of Manpower, 31(8), 848-870. http://dx.doi.org/10.1108/01437721011088548

Chen, Y.S., Lin, M.J.J., \& Chang, C.-H. (2006). The Influence of Intellectual Capital on New Product Development Performance - The Manufacturing Companies of Taiwan as an Example. Total Quality Management, 17(10), 1323-1339. http://dx.doi.org/10.1080/14783360601058979

Cohen, W. M., \& Levinthal, D. A. (1990). Absorptive Capacity: A New Perspective on Learning and Innovation. Administrative Science Quarterly, 35(1), 128-152. http://links.jstor.org/sici?sici=0001-8392\%28199003\%2935\%3A1\%3C128\%3AACANPO \%3 E2.0.CO\%3B2-5

Cooper, J. (1998). A multidimensional approach to the adoption of innovation. Management Decision, 36(8), 493-502. http://dx.doi.org/10.1108/00251749810232565

Dahiyat, S. E. \& Al-Zu'bi, Z. M. F. (2012). The role of knowledge acquisition in facilitating customer involvement in product development: examining the mediation effect of absorptive capacity. International Journal of Learning and Change, 6(3/4), 171-206. http://dx.doi.org/10.1504/IJLC.2012.050868

Damanpour, F. (1991). Organisational Innovation: A Meta-Analysis of Effects of Determinants and Moderators. Academy of Management Journal, 34(3), 555-590. http://dx.doi.org/10.2307/256406

Damanpour, F., \& Gopalakrishnan, S. (2001). The Dynamics of the Adoption of Product and Process Innovations in Organisation. Journal of Management Studies, 38(1), 45-66. http://dx.doi.org/10.1111/1467-6486.00227

Danneels, E. (2002). The dynamics of product innovation and firm competences. Strategic Management Journal, 23(12), 1095-1121. http://dx.doi.org/10.1002/smj.275

Diaz-Diaz, N., Aguiar-Diaz, I., \& De Saa-Perez, P. (2008). The Effect of Technological Knowledge Assets on Performance: The Innovation Choice in Spanish Firms. Research Policy, 37(9), 1515-1529. http://dx.doi.org/10.1016/j.respol.2008.06.002 
Dillman, D. (1978). Mail and Telephone Surveys: The Total Design Method. New York: Wiley.

Droge, C., Jayaram, J., \& Vickery, S.K. (2004). The effects of internal versus external integration practices on time-based performance and overall firm performance. Journal of Operations Management, 22(6), 557-573. http://dx.doi.org/10.1016/j.jom.2004.08.001

Edvinsson, L., \& Sullivan, P. (1996). Developing a model for managing intellectual capital. European Management Journal, 356-364. http://dx.doi.org/10.1016/0263-2373(96)00022-9

Edvinsson, L., \& Malone, M. (1997). Intellectual capital - Realizing your company's true value by finding its hidden roots. New York, NY: Harper Business.

Eisenhardt, K., \& Martin, J. (2000). Dynamic Capabilities: What are they? Strategic Management Journal, 21(10/11), 1105-1121. http://dx.doi.org/10.1002/1097-0266(200010/11)

Elsetouhi, A., \& Elbeltagi, I. (2011). The Relationship between Intellectual Capital and Process and Product Innovation in Banks: An Exploratory Study. Proceedings of the European Conference on Intellectual Capital, Plymouth University, School of Management, UK, 147-156.

Field, A. (2000). Discovering Statistics Using SPSS for Windows. London: Sage Publications.

Garcia, R., \& Calantone, R. (2002). A Critical Look at Technological Innovation Typology and Innovativeness Terminology: a Literature Review. Journal of Product Innovation Management, 19(2), 110-132. http://dx.doi.org/10.1016/S0737-6782(01)00132-1

Gopalakrishnan, S., Bierly, P., \& Kessler, E. (1999). A reexamination of product and process innovations using a knowledge-based view. The Journal of High Technology Management, 10(1), 147-166. http://dx.doi.org/10.1016/S1047-8310(99)80007-8

Grant, R. (1996). Prospering in Dynamically-Competitive Environments: Organisational Capability as Knowledge Integration. Organisation Science, 7(4), 375-387. http://www.jstor.org/stable/2635098

Hair, J., Anderson, R., Tatham, R. \& Black, W. (1998). Multivariate Data Analysis. (5th ed.). Upper Saddle River, NJ: Prentice-Hall.

Han, J. K, Kim, N., \& Srivastava, R. (1998). Market orientation and organizational performance: is innovation a missing link?. Journal of Marketing, 62, 30-45. http://www.jstor.org/stable/1252285

Harrison, S., \& Sullivan, P. H. (2000). Profiting from intellectual capital - learning from leading companies. Journal of Intellectual Capital, 1(1), 33-46. http://dx.doi.org/10.1108/14691930010324124

Hitt, M. A., Keats, B. W., \& DeMarie, S. M. (1998). Navigating in the new competitive landscape: Building strategic flexibility and competitive advantage in the 21 st century. 
Academy of Management Executive, 12(4), 22-42. http://www.jstor.org/stable/4165492

Hormiga, E., Canino, R., \& Sanchez-Medina, A. (2010). The role of intellectual capital in the success of new ventures. International Entrepreneurship and Management Journal, 7(1), 71-92. http://dx.doi.org/10.1007/s11365-010-0139-y

Huang, C. C., Luther, R., \& Tayles, M. (2007). An evidence-based taxonomy of intellectual capital. Journal of Intellectual Capital, 8(3), 386-408. http://dx.doi.org/10.1108/14691930710774830

Huber, G. (1991). Organisational learning: The contributing processes and the literatures. Organisation Science, 2(1), 88-115. http://www.jstor.org/stable/2634941

Hult, G., Hurley, R., \& Knight, G. (2004). Innovativeness: Its antecedents and impact on business performance. Industrial Marketing Management, 33, 429-438. http://dx.doi.org/10.1016/j.indmarman.2003.08.015

Hurley, R., Hult, G. (1998). Innovation, market orientation, and organizational learning: an integration and empirical examination. Journal of Marketing, 62, 42-54. http://www.jstor.org/stable/1251742

Iansiti, M., \& Clark, K. (1994). Integration and Dynamic Capability: Evidence from Product Development in Automobiles and Mainframe Computers. Industrial and Corporate Change, 3(3), 557-605. http://dx.doi.org/10.1093/icc/3.3.557

Jashapara, A. (2011). Knowledge Management: An Integrated Approach. UK: Prentice Hall

Katila, R., \& Ahuja, G. (2002). Something Old, Something New: A Longitudinal Study of Search Behavior and New Product Introduction. The Academy of Management Journal, 45(6), 1183- 1194. http://dx.doi.org/10.2307/3069433

López-Sáez, P., Navas-López, J. E., Martín-de-Castro, G., \& Cruz-González, J. (2010). External knowledge acquisition processes in knowledge-intensive clusters. Journal of Knowledge Management, 14(5), 690-707. http://dx.doi.org/10.1108/13673271011074845

Mayo, A. (2001). The Role of Employee Development in the Growth of Intellectual Capital. Personnel Review, 29(4), 521-533. http://dx.doi.org/10.1108/00483480010296311

Mention, A. (2012). Intellectual Capital, Innovation and Performance: a Systematic Review of the Literature. Business and Economic Research, 2(1). http://dx.doi.org/10.5296/ber.v2i1.1937

MERITUM (2002). MERITUM Guidelines for Managing and Reporting on Intangibles. Measuring Intangibles to Understand and Improve Innovation Management - Madrid: MERITUM.

Nahapiet, J., \& Ghoshal, S. (1998). Social capital, intellectual capital, and the organisational advantage. Academy of Management Review, 23(2), 242-266. http://www.jstor.org/stable/259373 
Namasivayam, K., \& Denizci, B. (2006). Human capital in service organisations: Identifying value drivers. Journal of Intellectual Capital, 7(3), 381-393. http://dx.doi.org/10.1108/14691930610681465

Narver, J., Slater, S., \& MacLachlan, D. (2004). Responsive and Proactive Market orientation and New Product Success. Journal of Product Innovation Management, 21(5), 334-347. http://dx.doi.org/10.1111/j.0737-6782.2004.00086.x

Nasution, H., Mavondo, F., Matanda, M., \& Ndubisi, N. (2011). Entrepreneurship: Its relationship with market orientation and learning orientation and as antecedents to innovation and customer value. Industrial Marketing Management, 40, 336-345. http://dx.doi.org/10.1016/j.indmarman.2010.08.002

Nonaka, I. (1994). A dynamic theory of organisational knowledge creation. Organisation Science, 5(1), 14-37. http://dx.doi.org/10.1287/orsc.5.1.14

Park, B. (2011). Knowledge transfer capacity of multinational enterprises and technology acquisition in international joint ventures. International Business Review, 20(1), 75-87. http://dx.doi.org/10.1016/j.ibusrev.2010.06.002

Petroni, A. (1998). The Analysis of Dynamic Capabilities in a Competence-Oriented Organisation. Technovation, 18(3), 179-189. http://dx.doi.org/10.1016/S0166-4972(97)00093-X

Roos, J., \& Roos, G. (1997). Measuring your company's intellectual performance. Long Range Planning, 30(3), 325. http://dx.doi.org/10.1016/S0024-6301(97)00022-8

Roos, J., G. Roos, N. Dragonetti, \& L. Edvinsson (1997). Intellectual Capital: Navigating the New Business Landscape. London: MacMillan Press.

Roos, J. (1998). Exploring the concept of intellectual capital (IC). Long Range Planning, 31(1), 150-153. http://dx.doi.org/10.1016/S0024-6301(97)87431-6

Sanchez, M.P., Chaminade, C., \& Olea, M. (2000). Management of intangibles: an attempt to build a theory. Journal of Intellectual Capital, 1(4), 312-327. http://dx.doi.org/10.1108/14691930010359225

Santos-Rodrigues, H., Dorrego, P., \& Jardon, C. (2010). The Influence of Human Capital on the Innovativeness of Firms. International Business \& Economics Research Journal, 9(9), 53-63.

Santos-Rodrigues, H., Dorrego, P., \& Jardon, C. (2011). Intellectual Capital and a Firm's Innovativeness. Proceedings of the European Conference on Intellectual Capital, ESTG-IPVC, Portugal and Universidade de Vigo, Pontevedra, Spain, 378-387.

Seleim, A., \& Khalil, O. (2011). Understanding the knowledge management-intellectual capital relationship: a two-way analysis. Journal of Intellectual Capital, 12(4), 586-614. http://dx.doi.org/10.1108/14691931111181742

Sinkula, J. M. (1994). Market information processing and organisational learning. Journal of 
Marketing, 58(1), 35-45. http://dx.doi.org/10.2307/1252249

Stevens, J. (2009). Applied Multivariate Statistics for the Social Sciences. (5th ed.). New York: Routledge.

Stewart, T. (1997). Intellectual Capital: The New Wealth of Organisations. New York: Currency.

Stewart, T. (2000). Intellectual Capital: The New Wealth of Organisations. London: Nicholas Brealey Publishing.

Subramaniam, M., \& Youndt, M. (2005). The influence of intellectual capital on the types of innovative capabilities. Academy of Management Journal, 48(3), 450-463. http://dx.doi.org/10.5465/AMJ.2005.17407911

Sveiby, K.E. (1997). The New Organisational Wealth: Managing and Measuring Knowledge-based Assets. San Francisco: Barrett-Kohler.

Sveiby, K.E. (1998). The intangible assets monitor. Journal of Human Resource Costing and Accounting, 2(1), 73 - 97. http://dx.doi.org/10.1108/eb029036

Teece, D. J., \& Pisano, G. (1994). The Dynamic Capabilities of Firms: an Introduction. Industrial and Corporate Change, 3(3), 537-556. http://dx.doi.org/ 10.1093/icc/3.3.537-a

Teece, D. J., Pisano, G., \& Shuen, A. (1997). Dynamic Capabilities and Strategic Management. Strategic Management Journal, 18(7), 509-533.

Teece, D. J. (2007). Explicating dynamic capabilities: the nature and microfoundations of (sustainable) enterprise performance. Strategic Management Journal, 28(13), 1319-1350. http://dx.doi.org/10.1002/smj.640

Trott, P. (2005). Innovation Management New Product Development. (3rd ed.). England: Pearson Education Limited.

Tsai, W., \& Ghoshal, S. (1998). Social capital and value creation: The role of intrafirm networks. Academy of Management Journal, 41(4), 464-476. http://dx.doi.org/10.2307/257085

Utterback, J. \& Abernathy, W. (1975). A Dynamic Model for Process and Product Innovation. Omega, 3(6), 639-656. http://dx.doi.org/10.1016/0305-0483(75)90068-7

Van Buren, M. (1999). A yardstick for knowledge management. Training and Development Journal, 53(5), 71-78. http://links.emeraldinsight.com/ref/28AR234

Wang, C. L., \& Ahmed, P. K. (2004). The development and validation of the organisational innovativeness construct using confirmatory factor analysis. European Journal of Innovation Management, 7(4), 303-313. http://dx.doi.org/10.1108/14601060410565056

Wang, Wen-Ying \& Chang, C. (2005). Intellectual capital and performance in causal models: Evidence from the information technology industry in Taiwan. Journal of Intellectual Capital, 6(2), 222 - 236. http://dx.doi.org/10.1108/14691930510592816 


\section{Macrothink}

Journal of Management Research

ISSN 1941-899X

2014, Vol. 6, No. 1

Weerawardena, J., \& O'Cass, A. (2004). Exploring the characteristics of the market-driven firms and antecedents to sustained competitive advantage. Industrial Marketing Management, 33, 419-428. http://dx.doi.org/10.1016/j.indmarman.2003.07.002

West, M. A., \& Anderson, N. R. (1996). Innovation in top management teams. Journal of Applied Psychology, 81(6), 680-693. http://dx.doi.org/10.1037/0021-9010.81.6.680

Wu, Wann-Yih, Chang, Man-Ling, \& Chen, Chih-Wei (2008). Promoting innovation through the accumulation of intellectual capital, social capital, and entrepreneurial orientation. $R \& D$ Management, 38(3), 265-277. http://dx.doi.org/10.1111/1467-9914.00120-i1

Xu, J., Houssin, R., Caillaud, E., \& Gordoni, M. (2010). Macro processes of knowledge management for continuous innovation. Journal of Knowledge Management, 14(4), 573-591. http://dx.doi.org/10.1108/13673271011059536

Youndt, M. A., Subramaniam, M., \& Snell, S. A. (2004). Intellectual Capital Profiles: An Examination of Investments and Returns. Journal of Management Studies, 41(2), 335-361. http://dx.doi.org/10.1111/j.1467-6486.2004.00435.x

Zahra, S.A., \& George, G. (2002). Absorptive capacity: a review, conceptualization, and extension. Academy of Management Review, 27(2), 185-204. http://www.jstor.org/stable/4134351

Zerenler, M., Hasiloglu, S. B., \& Mete, S. (2008). Intellectual Capital and Innovation Performance: Empirical Evidence in the Turkish Automotive Supplier. Journal of Technology Management and Innovation, 3(4), 31-40. http://dx.doi.org/10.4067/S0718-27242008000200003 